\title{
Origin of $\mathrm{Ni}-\mathrm{Cu}$-sulfide minerals in the komatiitic rock suite of the Archean Gorumahisani Greenstone belt, Singhbhum Craton (eastern India)
}

MR RATUL BANERJEE, MSC ${ }^{1}$, SISIR K MONDAL ${ }^{1}$ LAURIE REISBERG ${ }^{2}$ AND XIAOYU ZHOU ${ }^{3}$

${ }^{1}$ Jadavpur University

${ }^{2}$ Université de Lorraine, CNRS, CRPG

${ }^{3}$ CRPG-CNRS

Presenting Author: ratul.jugeology@gmail.com

The $\approx 120 \mathrm{~km}$ long, Archean Gorumahisani greenstone belt (Maharajgunj in the west to Kapili in the east) in the northeastern part of the Singhbhum Craton contains a komatiitic rock suite which is intercalated with a metasedimentary unit of the supracrustal sequence. This komatiitic suite is defined by serpentinized dunite at the bottom (adcumulate zone) that grades into platy, chevron and random spinifex textured serpentinized peridotite (spinifex zone) and then to komatiitic basalt at the top. Alongside chromite (altered to ferritchromit and Cr-magnetite), sulfide minerals are present as accessory phases $(\approx 1-3$ modal $\%)$ in the komatiitic dunite-peridotites. Pentlandite, millerite and cobaltian-millerite are present as disseminated phases throughout the komatiitic sequence whereas minor chalcopyrite, often rimmed by bornite is present as interstitial phases between serpentinized olivine of the lower adcumulate zone. Low temperature hydrothermal alteration of primary magmatic pentlandite and chalcopyrite results in the formation of patchy irregular millerite and thin rims of bornite, respectively. The cobalt-rich nature of the hydrothermal fluid may be responsible for the formation of cobaltian-millerite ( $\mathrm{Co} \approx 6.63-19.87 \mathrm{wt} . \%)$ along with minor enrichment of $\mathrm{Co}(\approx 0.5-2.25$ wt.\%) in pentlandite relative to the stoichiometric composition $(\mathrm{Co} \approx<1$ wt.\%). Small magnetite grains are associated with the pentlandite-millerite assemblage indicating an oxidizing nature for the hydrothermal fluid that drives the serpentinization process and leads to the release of $\mathrm{Fe}$ from pentlandite to form the millerite plus secondary magnetite. The serpentinization process released $\mathrm{Ni}$ from olivine, resulting in $\mathrm{Ni}$ enrichment of the hydrothermal liquid. The higher concentrations of As $(\approx 399-791$ ppm), $\mathrm{Ag}(\approx 3.53-17.8 \mathrm{ppm}), \mathrm{Sb}(\approx 0.97-60.1 \mathrm{ppm}), \mathrm{Pb}(\approx 51.3-$ $295 \mathrm{ppm})$ and $\mathrm{Bi}(\approx 37.4-319 \mathrm{ppm})$ in millerite and cobaltianmillerite support the contribution of hydrothermal fluid for modification of the primary sulfide assemblage within the komatiitic rock suite. 